\title{
Traditional Knowledge on Mushroom consumption habits of Amhara region in four selected districts; - Mecha, Fogera, BahirDarzuria and Zege
}

\author{
Birhanu Gizaw*, Zerihun Tsegay, Genene Tefera and Endegena Aynalem \\ Microbial Biodiversity Directorate, Ethiopian Biodiversity Institute, Ethiopia
}

Submission: January 16, 2018; Published: February 09, 2018

"Corresponding author: Birhanu Gizaw, Microbial Biodiversity Directorate, Ethiopian Biodiversity Institute, Addis Ababa, Ethiopia, Tel: +251911862561; Email: gbirhanu@ibc.gov.et

\begin{abstract}
Population growth coupled with increase in demand for food, domestication and scientific cultivation of wild edible mushroom is alternatives means to alleviate food shortage and malnutrition.The purpose of this study was to assess traditional wild mushroom consumption habit infour selected districts of Amhara region, Mecha, Zege, Fogera and Bahir Dar Zuria. In this study 115 adult individuals 81 males \& 34 females were selected and used as information source. Data were collected using structured open and close ended questionnaire, interview as well as personal observation. The study result indicated that (90.43\%) of the Mecha, Zege and Bahirdar Zuria Woreda residents have awareness about wild mushroom consumption and its various benefits.About $9.57 \%$ of the residents do not have an awareness especially Fogeradistrict. Wild mushroom collection was donemainly from cultivated farmland (65.21\%) followed by termite nests (14.78\%), uncultivated land (13.04\%), forestvicinity (5.21\%). All family members, children, women and men were involved in mushroom collection.

However, none of the inhabitants was found to cultivate mushrooms artificially in scientific ways due to various reasons, $63.48 \%$ respondents said lack of awareness on artificial mushroom cultivationmethod. 33.04\% respondent said non-availability of the well-known mushroom species, $3.47 \%$ respondeddue to religion pressure. All the inhabitants have stated the status of wild mushroom distribution has been sharply decreasing from time to time since the past two decades. They mentioned the cause of reduction are climate change (49\%), urbanization (13.51\%), chemical pollution $(12.57 \%)$, over overgrazing $(9.57 \%)$, unknown reason $(13.91 \%)$ followed by deforestation $(8.79 \% \%)$ reported by the respondents. From the current study, it is concluded that the majority of inhabitants like eating wild mushrooms traditionally and well aware about the current decrease in wild edible mushrooms distribution, they have neither cultivated nor are aware about the possibility of cultivating mushroom artificially, implying that there is an urgent need to initiate and create awareness among the inhabitants to adopt cultivation and conservation of such very important non-timber forest product in order to protect the decreasing status of the wild mushroom. As well as to decrease the lake Tana basin ecosystem destruction, Furthermore, such awareness and cultivation process could also be important to use the mushrooms for serving to diversify agricultural activity and supplement diet as well as income generation in the long run for the local farming community. It is requiring to domesticating wild edible mushroom through exploration and conservation of this bio resource fungi of the country at national fungal culture collection center.
\end{abstract}

Keywords: Cultivation; Mushroom; Pollution; Species; Wild

\section{Introduction}

Phylum Basdiomycota and Ascomycota are most terrestrial abundant fungi that have a great role to the environment and human kinds. Nowadays, interests are growing for biotechnological cultivation of Basidiomycetes mushrooms for food, bioactive molecules in pharmaceutical and cosmetic industries. Mushrooms have been attracting attention of mankind since ancient times, in its nutritional, medical, biotechnological properties and environmental applications. Today, approximately 14000 described mushroom species from 1.5 million fungi estimated, Out of which only 5-6 dozen edible mushroom have so far been artificially cultivated and commercially exploited all over the world addressing food security and medicinal application [1]. Currently, mushroom farming is being practiced in more than 100 countries and its production is increasing at the rate of 7 per cent per annum. The use of mushrooms as food is probably as old as civilization itself [2]. Mushrooms have also used as therapeutic foods, useful in preventing diseases such as hypertension, atherosclerosis, cancer, Hypoglycemic [3], Antitumor [4] Antioxidant [5] Anti-inflammatory, Antiallergic [6], Antiviral activity [7], Hypocholesterolemic [8]. And they are also engineers of forest ecosystem in maintaining and establishing of climax community through their capability in decomposition of lignocellulose waste in releasing essential nutrient and composting of forest soil. Mushroom cultivation 
and its research is a recent activity in Ethiopia started in 2001. The, food, medicinal, economic value and environmental role of Mushrooms have not been exploited so far. However, currently, there is increasing interest and production depending on 2- 4 exotic mushroom strain like Lentinusedodes, Agaricusbisporus, Pleurotusspp endeavors in some parts of the country [9]. Also the community indigenous knowledge on mushroom consumption habit regarding with medicinal and nutritional use were not assessed and collected in order to adapt artificial cultivation in small and large scale in the community. However, households in rural area and some ethnic group consume indigenous wild mushrooms traditionally by picking fruiting body where seasonally emerging. However internationally wild mushroom is domesticated and improved variety are recognized and utilized at industry scale in medicinal, nutritional and ecological manners very well. The Ethiopian wild indigenous mushrooms are not still explored, screened, identified and characterized to domesticate for home cultivation. As well as different species of wild mushroom and their habitat are not studied well. Therefore, there is little information available on wild mushrooms species of Ethiopia, especially collected from southern part like Kaffa and Asosa. Agaricuscampestris, L. sulphureus, T. clypeatus, T. microcarpus\#1, T. aurantiacus, T. letestui and Termitomycesspps [10]. Therefore this study is designed in aiming to assess wild mushroom consumption habit in four selected districts of Tana basin area in Amhara region specifically in Mecha, Zege, Fogera and BahirDarZuria in later to bring domestication for home cultivation in combating food insecurity and malnutrition, income generation, and to study wild mushroom distribution in different ecology and environmental application in turn to protect Tana basin ecosystem indirect destruction.

\section{Materials and Methods}

\section{Study area}

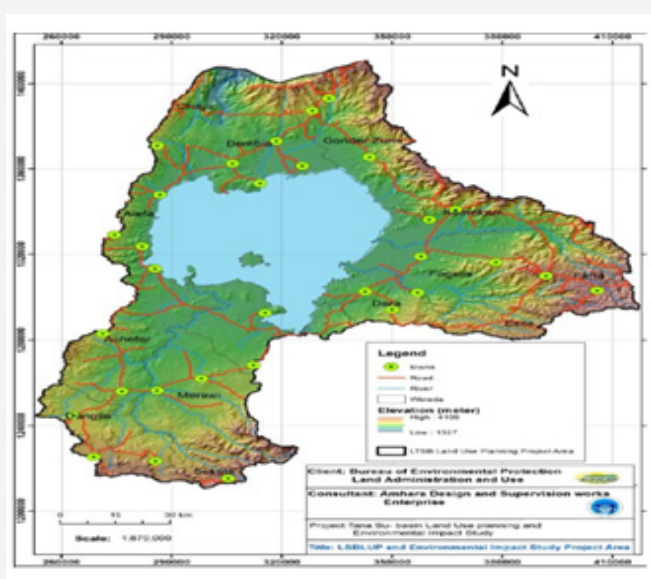

Figure 1: Map of the study.

The study was conducted Amhara region in Tana sub basin area in four selected districts particularly Mecha, Fogera, Bahirdarzuria, and Zege about $580 \mathrm{~km}$ away from Addis Ababa capital City of Ethiopia towards northern western Ethiopia. Tana Sub basin is found in the Amhara region. Geographically, the basin is located between North latitude $1210691.00 \mathrm{~m}$ to $1410799.77 \mathrm{~m}$ and East longitude $253026.62 \mathrm{~m}$ to $417182.92 \mathrm{~m}$. Its elevation is ranges 1327-4109 meter above sea level. The basin has a total area of 1,579,096.9 hectares. The largest lake in Ethiopia, Lake Tana is found in the sub basin. Parts or the whole of 29 Woredas and four administrative zones are encompassed in the subbasin (Figure 1)

\section{Data collection, sampling procedure and sample size}

In order to document and assess mushroom consumption habits and utilization practice in four district of amhara region both primary and secondary data were purposively collected. Structured and semi-structured open and close ended questionnaire was designed to collect information across the 115 listed elder informants. Both interviews in the village and field visit were made together. The questionnaires mainly focused on informants background and experience, their knowledge and use of wild mushrooms, period of mushroom consumption and frequency of collection, role of different media in creating awareness about mushrooms, status of mushroom in the past years, ability to distinguish edible from poisonous mushrooms, habitats and locations of mushroom sites, attitude and practice of mushroom cultivation (if any) and factors that initiate and hinder mushroom consumption and cultivation. Accordingly, about $10 \%$ (115) of elderly traditional resourceful inhabitants (81 males \& 34 females) of the kebele/village were identified and interviewed to solicit their local knowledge and attitude towards edible mushrooms. The sample size was determined by following Daniel (1995) procedure, and then a simple random sampling was used to select and collect information from the target 115 adult individuals purposively selected total elder house hold heads:

\section{Key informant interview}

Purposively the researcher selected 9 respondents who can be able to provide detail information regarding on the farmers traditional Knowledge on wild edible mushroom consumption practice and utilization in the study area. These include four leaders from district agriculture and rural development bureau and 5 elder leaders.

\section{Results}

\section{Socio-economic characteristics of the selected households (socio demographic data)}

The study covered 23group informants having 115adult individuals in 4 districts Amhra Regional state. From all studyparticipants $29.57 \%$ were females and $70.43 \%$ weremales. The age groups of interviewed farmers in this study were different age ranges; 20-40 years (59.14\%), followed by 4150 years (18.27\%), 51-60 years (15.54\%) and above 61 years old $(6.09 \%)$. In general $77.41 \%$ of the population involved in 
the study was the age in between 0-50years old. With regard torespondenteducational status $81.74 \%$ illiterate, $13.9 \%$ primary school and $4.34 \%$ secondary school. With regard to ethnic group, family size, respondent's income source, farm size, marital status, occupation summarized in Table 1.

Table 1: Socio -Demographic Characteristics of the Study Population.

\begin{tabular}{|c|c|c|c|c|c|c|c|}
\hline Variables & Factors & Bahirdarzuria & Zege & Mecha & Fogera & Total No & percentage \\
\hline \multirow{2}{*}{ Sex } & Male & 41 & 15 & 16 & 9 & 81 & 70.43 \\
\hline & Total & 60 & 24 & 18 & 13 & 115 & $100 \%$ \\
\hline \multirow{5}{*}{ Age } & $20-40$ & 39 & 14 & 5 & 10 & 68 & 59.14 \\
\hline & $41-50$ & 14 & 3 & 3 & 1 & 21 & 18.268 \\
\hline & $51-60$ & 7 & 4 & 7 & 1 & 19 & 15.54 \\
\hline & $>61$ & 0 & 3 & 3 & 1 & 7 & 6.09 \\
\hline & Total & & 24 & 18 & 13 & 115 & \\
\hline \multirow{3}{*}{ Marital status } & Single & 0 & 2 & 2 & 1 & 5 & 4.35 \\
\hline & Married & 60 & 22 & 16 & 12 & 110 & 95.65 \\
\hline & Divorced & 0 & 0 & 0 & 0 & 0 & 0 \\
\hline \multirow{4}{*}{ Religion } & Orthodox & 60 & 24 & 18 & 13 & 115 & 100 \\
\hline & Muslim & 0 & 0 & 0 & 0 & 0 & 0 \\
\hline & Protestant & 0 & 0 & 0 & 0 & 0 & 0 \\
\hline & Catholic & 0 & 0 & 0 & 0 & 0 & 0 \\
\hline \multirow{6}{*}{ Ethnicity } & Amhara & 60 & 24 & 18 & 13 & 115 & 100 \\
\hline & Oromo & 0 & 0 & 0 & 0 & 0 & 0 \\
\hline & Tegrie & 0 & 0 & 0 & 0 & 0 & 0 \\
\hline & Guragie & 0 & 0 & 0 & 0 & 0 & 0 \\
\hline & Other & 0 & 0 & 0 & 0 & 0 & 0 \\
\hline & Total & & & & & & \\
\hline \multirow{6}{*}{ Annual income } & $<1000$ & 9 & 0 & 5 & 1 & 15 & 13.04 \\
\hline & $1000-2000$ & 26 & 10 & 4 & 5 & 45 & 39.13 \\
\hline & 2001-3000 & 7 & 3 & 0 & 1 & 11 & 9.56 \\
\hline & $3001-4000$ & 4 & 3 & 0 & & 7 & 6.09 \\
\hline & $>4001$ & 14 & 8 & 9 & 6 & 37 & 32.17 \\
\hline & Total & 60 & 24 & 18 & 13 & 115 & \\
\hline \multirow{6}{*}{ Family size } & $>10$ & & & & & & 0 \\
\hline & 07-Sep & 23 & 6 & 7 & 5 & 41 & 35.65 \\
\hline & 04-Jun & 10 & 13 & 10 & 5 & 38 & 33.04 \\
\hline & 01-Mar & 27 & 3 & & 3 & 33 & 28.69 \\
\hline & 0nly 1 & 0 & 2 & 1 & 0 & 3 & 2.61 \\
\hline & Total & 60 & 24 & 18 & 13 & 115 & \\
\hline \multirow{5}{*}{ Occupation } & Farmer & 36 & 18 & 16 & 11 & 81 & 70.43 \\
\hline & House wife & 14 & 3 & 2 & 2 & 21 & 18.26 \\
\hline & merchant & 0 & 1 & 0 & 0 & 1 & 0.87 \\
\hline & Other & 0 & 2 & 0 & 0 & 2 & 1.74 \\
\hline & Total & 60 & 24 & 18 & 13 & 115 & \\
\hline \multirow{4}{*}{ Education } & Primary & 0 & 6 & 8 & 2 & 16 & 13.9 \\
\hline & secondary & 0 & 1 & 0 & 4 & 5 & 4.34 \\
\hline & Illiterate & 60 & 17 & 10 & 7 & 94 & 81.74 \\
\hline & Total & 60 & 24 & 18 & 13 & 115 & \\
\hline
\end{tabular}




\section{Awareness on mushroom consumption and utilization practice inthe study area}

One hundred four (90.43\%) respondents of Mecha, Zege and Bahir Darzuriadistrict have awareness about mushroom consumption and utilization practice, few respondents especially from Fogera districts (9.57\%) did not have information about mushroom consumption in their area elsewhere. Respondents were asked about contribution of various information source about use and mushroom consumption. About 67.82\% respondents replied that they have got knowledge about wild mushroom from elderly person followed by friends (10.43\%) and agricultural centers (3.48\%) respectively, similarly, media such as radio accounted only about (8.7\%) (Figure 2). Among respondents who had reasons for eating mushroom $(86.08 \%)$ of them said that they eat mushroom because of it has good taste, $(5.22 \%)$ eat mushroom because of its high nutritional value and $(6.08 \%)$ of the inhabitants responded that mushrooms may be substitute fish and meat, and others (2.61\%) of respondent they do not know the reason why they eat mushroom (Figure 3 ).

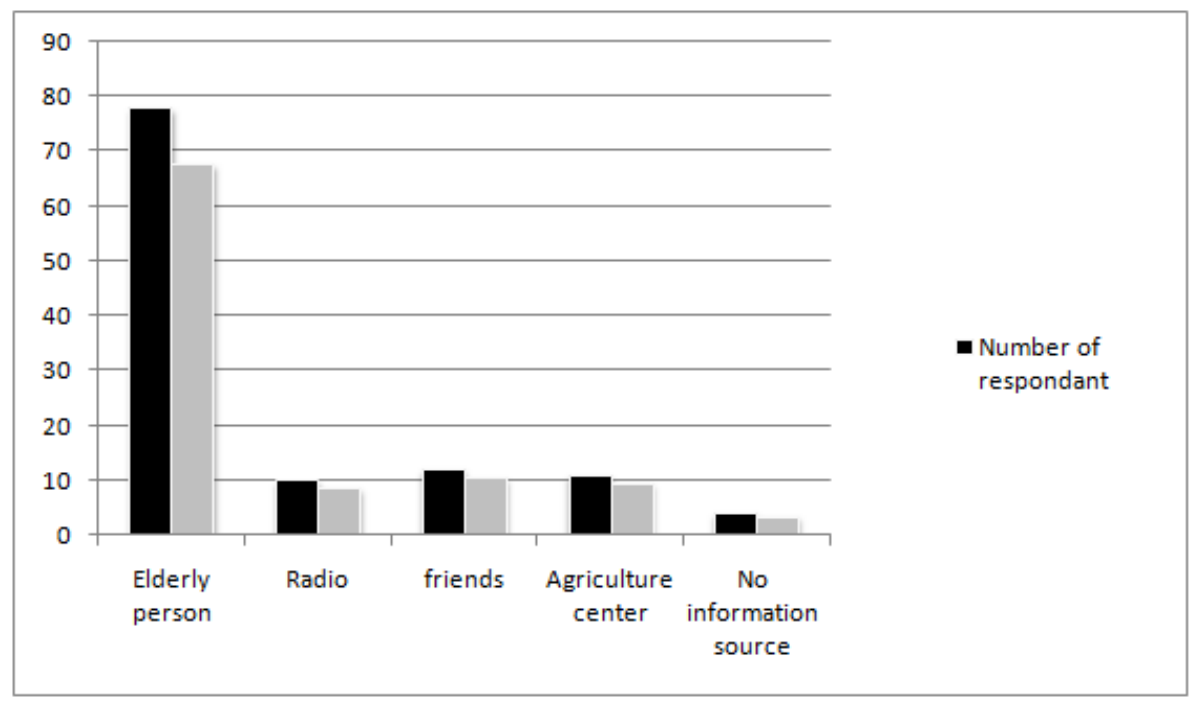

Figure 2: Contribution of various sources of information about mushroom consumption.

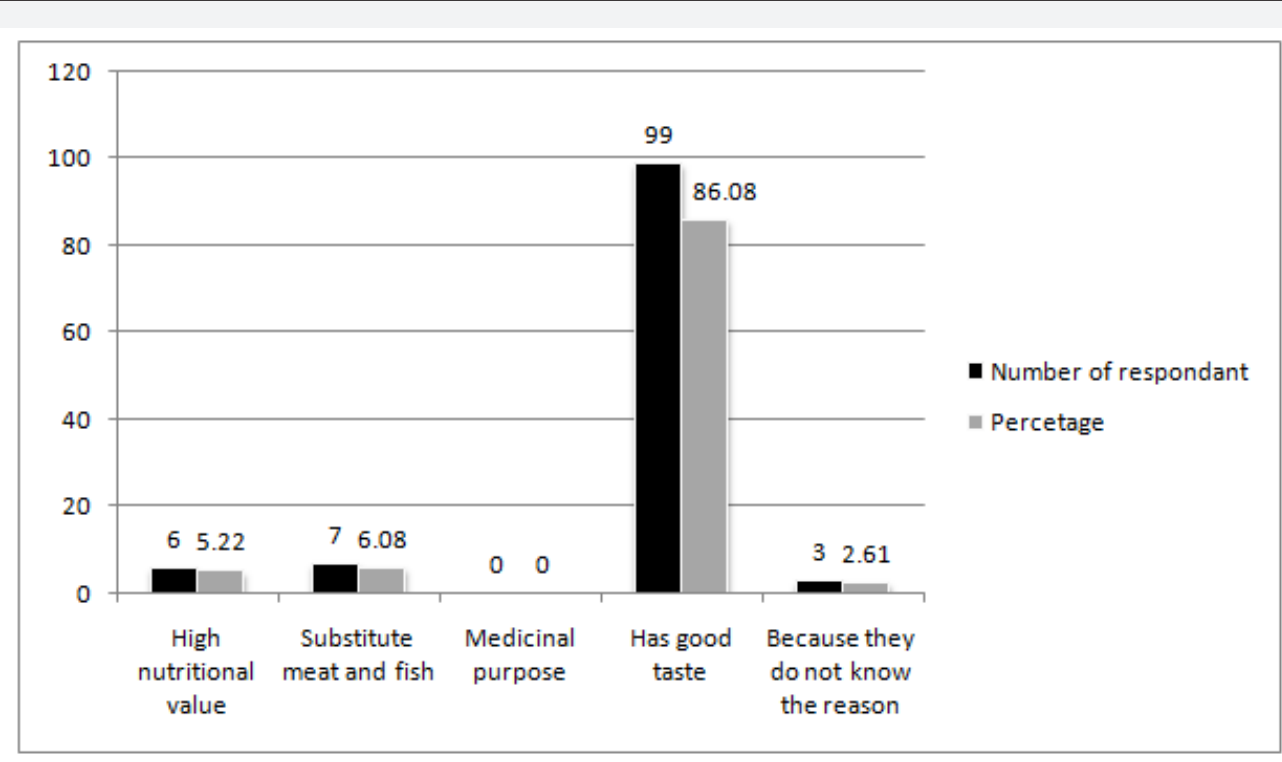

Figure 3: Respondents reasons for eating mushrooms. 


\section{Frequency and sites of mushroom collection in the study district}

Respondents (87.83\%) mentioned that the collection of mushroom depends on seasonal variation. This study revealed that, the wild edible mushroom was mainly (65.21\%) collected from cultivated farm land and collection carried out in different area like from termite nest, uncultivated farm land, forest vicinity the little collection is done at wood land. All percentage of collection is summarized in (Table 2). If the collection was nearby to residence, usually women, children, shepherd frequently involved to collect while men mostly involved in collecting from a distant and forest area and vicinity. From the total of 115 respondents, $83.47 \%$ of them responded that mushrooms were collected sometimes, $7.83 \%$ of the respondents indicated that mushroom can be gathered when needed and the remaining $(8.7 \%)$ of them reported that they do not collect mushrooms at any time (Table 3).

Table 2: Mushroom Collection and Abundance site.

\begin{tabular}{|c|c|c|}
\hline $\begin{array}{c}\text { Mushroom Collection and } \\
\text { Abundance Site }\end{array}$ & Respondent & Percentage \\
\hline Forest in the vicinity & 6 & $5.21 \%$ \\
\hline Uncultivated land & 15 & $13.04 \%$ \\
\hline Termite nest & 17 & $14.78 \%$ \\
\hline Woodland & 1 & $0.87 \%$ \\
\hline Cultivated Farm land & 75 & $65.21 \%$ \\
\hline Other & 1 & $0.87 \%$ \\
\hline
\end{tabular}

Table 3: Frequency of collection by inhabitants when mushrooms are available.

\begin{tabular}{|c|c|c|}
\hline $\begin{array}{c}\text { Frequency of Collection by Inhabitants } \\
\text { (when Mushrooms are Available) }\end{array}$ & No of Respondent & Percentage \\
\hline Gather some times & 96 & $83.47 \%$ \\
\hline Gather when needed & 9 & $03 \%$ \\
\hline Gather every day & 0 & $8.70 \%$ \\
\hline They do not want to collect any time & 10 & $03 \%$ \\
\hline
\end{tabular}

Knowledge of respondents in differentiating wild mushroom as edible and poisons

The impressing point about the respondent of study area distinguish between edible and non-edible wild mushrooms and they gave different reasons such as mushrooms could be poisonous, may have bad smell, color difference, visited by many insects, and the morphology of mushroom were some reasons for not consuming those non-edible mushrooms (Table 4).

Table 4: Knowledge of respondents in differentiating wild mushroom as edible and poisons.

\begin{tabular}{|c|c|c|c|c|}
\hline S. No & No Variable & Response & Number of Respondents & $\%$ \\
\hline \multirow{2}{*}{1} & \multirow{2}{*}{$\begin{array}{l}\text { Are there wild edible } \\
\text { mushroom in your } \\
\text { locality? }\end{array}$} & Yes & 103 & 89.56 \\
\hline & & No & 11 & 10.43 \\
\hline \multirow[b]{2}{*}{2} & \multirow{2}{*}{$\begin{array}{c}\text { Are there wild } \\
\text { mushroom which you } \\
\text { do not eat? }\end{array}$} & Yes & 86 & $74.78 \%$ \\
\hline & & No & 29 & $25.21 \%$ \\
\hline \multirow{5}{*}{3} & \multirow{4}{*}{$\begin{array}{l}\text { Reasons for not } \\
\text { consuming non edible } \\
\text { mushrooms }\end{array}$} & Poisonous & 3 & $2.61 \%$ \\
\hline & & No good smell & 24 & $20.87 \%$ \\
\hline & & Visited by many insects & 16 & $13.90 \%$ \\
\hline & & Because other People do not eat them & 72 & $62.61 \%$ \\
\hline & \multicolumn{2}{|r|}{ Total } & 115 & $100 \%$ \\
\hline
\end{tabular}

\section{Mushroom as food source}

Among those respondents who used mushroom as food source, the majority (66.96\%) of them cooked as 'wot' and $28.69 \%$ of them fried/roasted whereas only about $4.34 \%$ respondents indicated that they utilize fresh (raw) mushroom. And the type of edible mushroom they prefer to eat is Agaricus spp, followed by Termytomyces spp. A significant number of respondents mentioned that there is no obstacle that discourages to consume mushroom However, (63.48\%) mentioned that lack of awareness is a discouraging factor for mushroom cultivation\& consumption in scientific way. In addition, about $33.04 \%$ of respondents indicated that non availability of mushroom species all the time could be a reason for discouraging mushroom consumption and similarly, few (3.47\%) of respondents mentioned that religion was a reason to be considered as obstacle to constraint mushroom consumption (Table 5) inhabitant call wild edible mushroom in their locality as Engudy, filit and mitatite where those non edible locally called as Abagonfagonfi, abahoyfus and the like. All the respondents (100\%) did not cultivate mushroom in scientific way in the study area to various reason. Table 5 summarize the reason for not cultivating mushroom (Figure 3). 
Table 5: Reasons for not cultivating mushroom.

\begin{tabular}{|c|c|c|c|}
\hline \multirow{2}{*}{ S. No } & Reasons for not Cultivating & \multicolumn{2}{|c|}{ Respondent } \\
\cline { 2 - 4 } & Lack of awareness & 73 & $63.48 \%$ \\
\hline 1 & Non-availability of the well-known domesticated wild mushroom & 38 & $33.04 \%$ \\
\hline 3 & Species & 4 & $3.47 \%$ \\
\hline & Religion pressure & 115 & $100 \%$ \\
\hline
\end{tabular}

\section{Conditions under which people eat wild edible mushroom}

Among the respondents, $64.35 \%$ stated that they eat wild mushroom when they encounter by chance, others $4.35 \%$

Table 6: Conditions under which people eat wild edible mushroom. respondents ate wild edible mushroom when they are attracted by good smell. However, the other $31.31 \%$ inhabitants answered that they do not know the reason they eat wild mushroom (Table 6) (Figure 4).

\begin{tabular}{|c|c|c|c|}
\hline \multirow{2}{*}{ S. No } & Season or Frequency and/or Condition Under Which People Eat & \multicolumn{2}{|c|}{ Respondent } \\
\cline { 3 - 4 } & Wild Edible Mushroom & No & \multirow{2}{*}{0} \\
\hline 1 & They eat always & 0 & 0 \\
\hline 2 & During shortage of food at home & 0 & 64.35 \\
\hline 3 & They eat when encountered by chance & 74 & 4.35 \\
\hline 4 & They eat when they are attracted by good smell & 5 & 31.31 \\
\hline 5 & They do not know the reason they eat & 36 & 115 \\
\hline
\end{tabular}

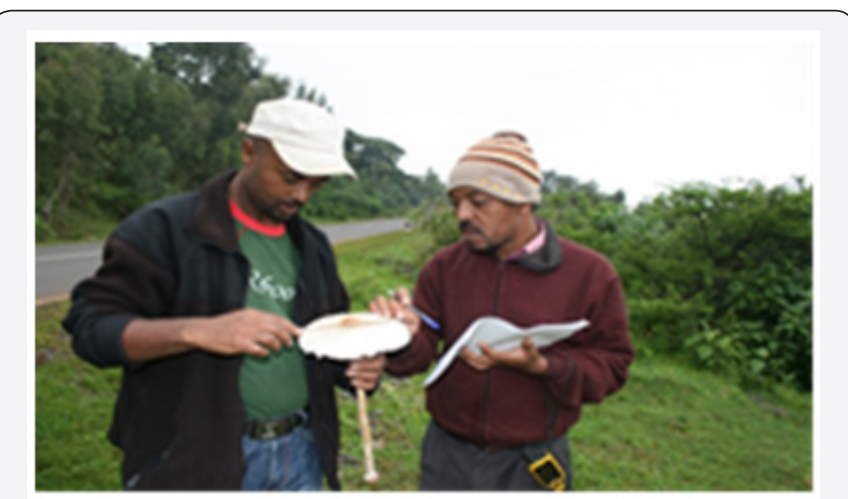

Figure 4: (Morphologic identification).
Reasons for decreasing trend of wild edible mushrooms distribution

Regarding the current status of wild mushroom (both edible \& non-edible) at Amhara region in 4 districts particularly Zege, Bahirdarzuriawerda, Mecha and Fogera, all of the 115 respondants indicated that there is a sharp decrease in mushroom as compared to previous years particularly in the past two decades. The main reasons for decreasing mushroom distribution in the current study were attributed to climate change (49\%), urbanization (13.51\%), chemical pollution $(12.57 \%)$ over overgrazing $(9.57 \%)$, unknown reseason (13.91) followed by deforestation $(8.79 \%)$ as reported by the respondents (Figure 5).

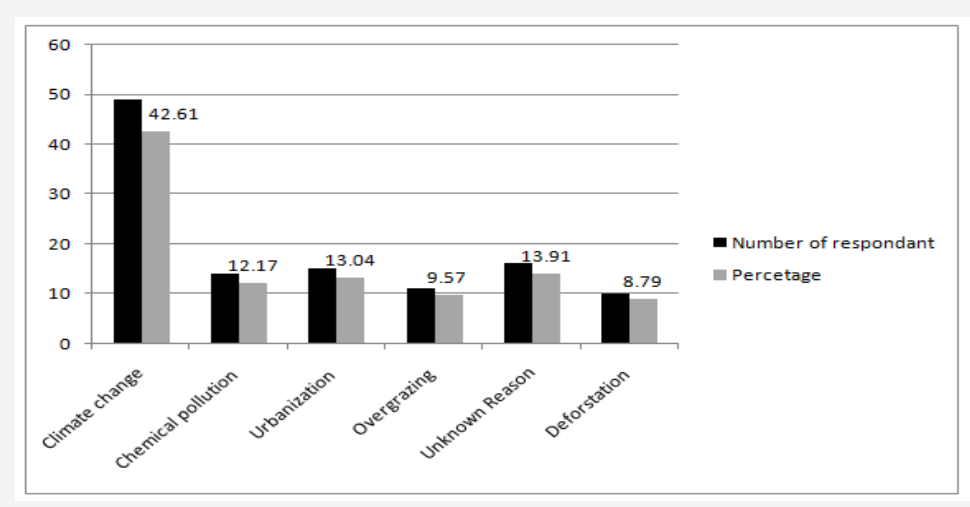

Figure 5: Reasons for decreasing trend of wild edible mushrooms distribution. 


\section{Discussion}

Population growth in Ethiopia coupled with increase in demand for food, cultivation of mushroom can be one of the alternatives means to address nutritional security in relatively small farm space and cheap substrates such as agricultural wastes. In 3 districts of Amhara region particularly Zege, mecha and Bahirdarzuriawordapeople consume mushrooms according to respondent response with the understanding of told by elderly person, their potential substitute of meat and fish, as well as good flavor. Firenzuoli et al. [11] has also reported mushrooms to be sources of water (90\%), protein (2-40\%), fat (28\%), carbohydrates (1-55\%), fiber $(3-32 \%)$ and ash (8-10\%). Furthermore, there is a large body of report that reveals various uses of mushrooms (functional food, and as natural therapy in the form of a medicinal extract mostly for prevention and treatment of cancer as well as other diseases) in countries like China and Japan as stated by [11]. High fiber content, proteins, microelements and lower caloric content are found almost ideal for a nutrition program aimed to the prevention of hypercholesterolemia and cardiovascular diseases [12]. Similarly, the use of mushroom for anti-cancer activities [13], reduction of total blood cholesterol and lipoprotein cholesterol [14], antioxidant activities, the regulation of blood lipid levels and reduction of blood glucose levels [15] have been reported. Studies also revealed that the United Nations Food and Agriculture Organization (FAO) strongly advices the consumption of mushroom due to their high nutritional and medicinal values [16]. The fact that elderly people contribute more in initiating mushroom consumption indicates that they are well aware about the nutritional and/or medicinal values of mushroom. In addition, experience of using wild edible mushroom in the area for a long time by the local people may also help to easily adopt the cultivation activity if supported by concerned body in the future. In this study, there is less involvement of various information sources such as religious places as well as radio, which is relatively the most available medium particularly among the rural communities and could have played major role in disseminating messages about the importance of mushroom. The little use of such means of information dissemination is a clear indication to work more in promotion and creating awareness among the inhabitants in the future. Mayett et al. [17] reported media and traditional recipes have important roles in increasing demand among consumers by creating awareness. Wild edible mushrooms are important food sources for rural communities such as Amhara region inhabitants particularly during the rainy season as observed during this study like in many regions of the world. In the present study, in 3 districts of Amhara region people are very keen in differencing between the wild edible mushrooms from non-edible ones, experiences that came through oral communications from their elders. This is very interesting in that coupling such traditional knowledge with scientific description and identification of the edible fungi will have paramount advantage in sustainable utilization of the resource for various obvious purposes in the area as well as elsewhere in the region. Furthermore, such local knowledge could be even more important for people who are not familiar to the area as one should eat mushrooms only if one knows their names and their properties with considerable precision. There has been significant trend of decreasing mushroom in the past years as confirmed from the residents of study area mainly due to climate change, chemical pollution as well as decline forest coverage in the area. Since there has been expansion of agricultural land around the study area in the past years due to human population pressure, it was clear that deforestation is the main factor to reduce such essential on-timber forest product. It is also logical that chemicals (particularly agrochemicals) were additional factors to seriously affect the mushroom distribution as farmers use the chemicals to boost crop production. Similarly, alarming decline in wild edible mushroom populations has been reported from central part of Burkina Faso which was closely linked to disappearing forest habitats [18]. On the other hand, in countries like Japan, the Republic of Korea, China, and the Russian Federation, the tradition of eating wild edible fungi is much stronger and appears to have withstood the changes experienced elsewhere as stated by [19]. Hence, the population of wild edible mushroom is increasing in some of the developed countries probably due to better management of natural forests in contrast to the trend seen in developing countries. Regardless of remarkable knowledge and interest of the local residents about mushroom consumption and its importance in the study area, it is evident that there are severe weaknesses to initiate mushroom cultivation. For instance, there are little efforts by schools, agricultural experts and health workers to create awareness among consumers about importance of mushroom consumption and cultivation. Existence of apparent discrepancy between mushroom knowledge and infrequent mushroom consumption probably due to social valuation of mushrooms has been reported [20] among local people by a study made in Cameron. However, in contrast to the current study, cultivation activities of mushrooms have been observed to serve various purposes in different countries. For instance, in Japan mushroom cultivation is an income generating activity both in rural and urban areas [12]. Similarly, in some African countries such as Benin and Cameroon, mushroom cultivation generates income, particularly for women thereby contributing to their economic independence [20]. Though none of the residents in the study area were involved in mushroom cultivation due to various reasons, the majority have remarkable interest of mushroom adoption. Such interest of the people to adopt mushroom is in agreement with investigation made in countries likeJapan and China, in which the people strongly accept mushrooms cultivation for their obvious nutritional and medicinal values [15]. However, concerning some respondents who did not support mushroom cultivation explaining that it takes farmland, it looks that the farmers may not be well aware about productivity of mushrooms in relatively small area. On the other hand, Suman \& Sharma [21] have reported1000 time's higher production of mushroom protein and good amino acid 
content per unit area. Furthermore, contribution of mushrooms to make valuable addition to the often unbalanced diets of people in developing countries [16] as well as their potential as substitutes to muscle protein and digestibility (89\%) have already been documented [16]. The study area due to climate change, deforestation, chemical pollution, and urbanization and over grazing mushroom calls for the need for environmental protection and awareness creation as well as technical support to enable the local inhabitants adopt mushroom cultivation. Moreover, detail diversity and distribution of mushrooms in the area and the region at large should be encouraged for better utilization of such environmentally friendly non-timber forest product.

\section{Conclusion}

In this study area majority of inhabitants in 3 districts of Mecha, bahirdarzuriaworeda, Zege, have awareness about wild mushroom consumption and they like to eat mushroom (mycophilic) because they believe that eating mushroom has good taste and substitute's meat and fish. But the Fogera inhabitants do not have well awareness. However, as there is no intentional mushroom cultivation, there is a need to support the local people and establish at least small-scale mushroom farms, and small scale enterprise that could enable the farmers to produce not only for own consumption but it may also serve as additional income as they may supply to local hotels and restaurants in addition to creating job opportunity. The fact that there is decreasing trending distribution of edible mushrooms in the study area due to deforestation, chemical pollution, and urbanization and over grazing which need for environmental protection and awareness creation as well as technical support to enable the local inhabitants adopt wild mushroom cultivation. Moreover, detail diversity and distribution of mushrooms in the area requiring survey, documentation and conservation of mushroom spore and tissue in national fungal culture collection center and the region at large should be encouraged for better utilization of such environmentally friendly non-timber forest product. There are many gaps in our knowledge of which benefits from sales and consumption of these fungi, and future studies need to emphasize the critical role that people have in making choices and developing opportunities. Local communities benefit much from sales though scientific cultivation. And wild edible mushrooms are only one of many strategies that rural people use to earn a living.

\section{Recommendation}

The government should give great attention and facilitate scientific mushroom cultivation training for local community. Awareness creation as long as adoption of wild mushroom cultivation practically must done with the selected group of the community. Proper institutional arrangements are required make survey and conservation this forgotten wild edible mushroom. The government facilitates to supply the good quality of spawn at reasonable prices and in desired quantities to the mushroom growers. Farmers' co-operative marketing societies and/or farmer's organizations may be promoted to take care of surplus quantity of mushroom production. In order to satisfy the demand an increase in the domestic supply of fresh mushrooms may probably enhance modern farms. These farms can achieve lower production costs, apply effective organization in their value chain, seek and develop special products with increased added value and increase their negotiating ability in the food market.

\section{References}

1. Moore D, Chi SW (2005) Fungi products as food. In: Pointing SB, Hyde KO (Eds.), Bio- Explotation of filamentous fungi. Fungi Diversity Res Lenis 6: 223-251.

2. Chaube HS (1995) Nutritional and Medicinal value of Mushroom. Mushroom production Technology, University of Agriculture and Technology, India, pp. 1-6.

3. Gray AM, Flatt PR (1998) Insulin-releasing and insulin-like activity of Agaricus Campestris (mushroom). J Endocrin 157(2): 259-266.

4. Lucas EH, Byerrum M, Clarke DA, Reilly HC, Stevens JA, et al. (1958) Production of oncostatic principles in vivo and in vitro by species of the genus Calvatia. Antibiot Annu 6: 493-496.

5. Mau JL, Lin HC, Song SF (2002) Antioxidant properties of several specialty mushrooms. Food Res Int 35: 519-526.

6. Ali NA, Pilgrim H, Ludke J, Lindequist U (1996) Inhibition of chemiluminescence response of human mononuclear cells and suppression of mitogen induced proliferation of spleen lymphocytes of mice by hispolon and hispidin. Pharmazie 51: 667-670.

7. Awadh AAN, Mothana RA, Lesnau A, Pilgrim H, Lindequist U (2003) Antiviral activity of extracts and compounds from Inonotush ispidus. Fitoterapia 74: 483-485.

8. Ryong LH, Tertov VV, Vasiley AW, Tutelyan VA, Orekhov AN (1989) Antiatherogenic and antiatherosclerotic effects of mushroom extracts revealed in human aortic intima cell culture. Drug Develop Res 17: 109117.

9. Dawit A (1998) Mushroom cultivation: A practical approach. Berhanena Selamprinting press, Addis Ababa, Ethiopia, pp. 17-72.

10. Ashagrie ZW, Dawit Abate, Gulelat D Haki, Gregory R Ziegler (2015) Proximate and Amino Acid Composition of Wild and Cultivated Edible Mushrooms Collected from Ethiopia. Journal of Food and Nutrition Sciences 3(2): 48-55.

11. Firenzuoli F, Gori L, Lombardo G (2008) The Medicinal Mushroom Agaricusblazei Murrill: Review of Literature and PharmacoToxicological Problems. Evid Based Complement Alternat Med 5(1): 3-15.

12. Daba AS, Kabeil SS, Botros WA, El-Saadani MA (2008) Production of mushroom (Pleurotusstreatus) in Egypt as source of nutritional and Medicinal food. World J Agr Soc 4: 630-634.

13. Mizuno T (1999) The extraction and development of antitumour-active polysaccharides from Medicinal mushrooms in Japan. International Journal of Medicinal Mushrooms 1:9-29.

14. Gue SC, Woo SJ, Hyo CJ, Kwan CC, Heui YC, et al. (2006) Macrophage activation and nitricoxide production by water soluble component of Hericiumer inaceum. International-Immunopharmacology 6(8): 13631369

15. Marshall E, Nair NG (2009) Make money by growing mushrooms. Food and Agriculture Organization of the United Nations, Rome, Italy.

16. Mayett Y (2006) Consumption Trends of Edible Mushrooms in Developing Countries: The Case of Mexico Journal of International Food \& Agribusiness Marketing 18(1-2) 
17. Guissou KML, Lykke AM, Sankara P, Guinko S (2008) Declining wild mushroom recognition and usage in Burkina Faso. Econ Bot 62(3): 530-539.

18. Boa E (2004) Wild edible fungi. A global overview of their use and importance to people. Non- Wood Forest Products 16 . FAO, Rome, Italy.
19. Van Dijk H, Onguene NA, Kuyper TW (2003) Knowledge and utilization of edible mushrooms by local populations of the rain forest of south Cameroon. Ambio 32(1): 19-23.

20. Suman, BV Sharma (2007) Mushroom Cultivation in India, pp. 56.
This work is licensed under Creative

Commons Attribution 4.0 License

DOI: 10.19080/JOJHA.2018.01.555552

\section{Your next submission with Juniper Publishers} will reach you the below assets

- Quality Editorial service

- Swift Peer Review

- Reprints availability

- E-prints Service

- Manuscript Podcast for convenient understanding

- Global attainment for your research

- Manuscript accessibility in different formats

( Pdf, E-pub, Full Text, Audio)

- Unceasing customer service

Track the below URL for one-step submission https://juniperpublishers.com/online-submission.php 